\title{
HUBUNGAN TIMBAL BALIK ANTARA ARUS MASUK FOREIGN DIRECT INVESTMENT DAN HUMAN CAPITAL DI INDONESIA DAN INDIA ${ }^{1}$
}

\author{
Raden Fiat Mahadhika Ramzy² \\ PT United Tractors Tbk
}

\begin{abstract}
Foreign Direct Investment (FDI) benefits the host country by technology transfer and spillover effect toward its workforce. Meanwhile, the quality of human capital (HC) in the host country may attract FDI. This study aims to examine the relationship of FDI inflow and the quality of HC in Indonesia and India and to investigate FDI orientation. Applied two-stage least square to time series data of the year 2000-2015, the result shows a causal relationship between FDI and HC in Indonesia, but oneway relationship from FDI to HC in India. Government spending on education and health has positive effects on HC in both countries. In Indonesia, FDI is positively affected by HC and growth, while in India, only by country risk index.
\end{abstract}

Keywords: Foreign Direct Investment, human capital, two stage least square

\begin{abstract}
ABSTRAK
Foreign Direct Investment (FDI) bermanfaat bagi negara tuan rumah dengan transfer teknologi dan spillover effect terhadap tenaga kerja. Di sisi lain, kualitas human capital (HC) negara tuan rumah merupakan daya tarik bagi FDI. Penelitian ini bertujuan menguji hubungan antara arus masuk FDI dan kualitas HC di Indonesia dan India dan mengetahui orientasi FDI. Dengan metode two stage least square pada data time series tahun 2000-2015, ditemukan bahwa terdapat hubungan kausalitas antara FDI dengan HC di Indonesia, namun di India hanya terdapat hubungan satu arah yaitu FDI terhadap HC. Pengeluaran pemerintah di sektor pendidikan dan kesehatan positif memengaruhi HC di kedua negara. Di Indonesia, FDI positif dipengaruhi oleh HC dan pertumbuhan ekonomi, sedangkan di India, FDI hanya dipengaruhi indeks risiko negara.
\end{abstract}

Kata kunci: Foreign Direct Investment, human capital, two stage least square

\section{PENDAHULUAN}

Foreign Direct Investment (FDI) didefinisikan sebagai investasi yang melibatkan hubungan dan kepentingan jangka panjang serta pengendalian oleh investor asing langsung atau perusahaan induk yang berada di negara lain (WIR, 2010). Dalam beberapa tahun terakhir terjadi peningkatan arus FDI di dunia. Menurut World Invesment Report (WIR), seperti dikutip oleh Soltanpanah dan Karimi (2013), lonjakan arus masuk FDI terjadi sejak sekitar tahun 1980. Tahun 2006 peningkatan arus masuk FDI ke berbagai negara di dunia mencapai 38\%, tertinggi dibandingkan tahun-tahun sebelumnya. Derasnya arus FDI dikaitkan dengan perekonomian dunia yang semakin kuat.

FDI yang masuk ke sebuah negara membuka lapangan pekerjaan, lalu memberikan dampak lain berupa penerimaan pajak sehingga pendapatan dan belanja negara dapat ditingkatkan. FDI dipandang sebagai faktor penting dalam mendorong pertumbuhan ekonomi, memperbesar modal untuk meningkatkan produktivitas, lapangan kerja, inovasi dan teknologi

\footnotetext{
${ }^{1}$ Penulis mengucapkan terima kasih kepada Ibu Januarita Hendrani, atas bimbingannya dalam melakukan penelitian ini.

${ }^{2}$ Email: fiatmahadhika@gmail.com
} 


\section{4 | Bina Ekonomi}

(Dorozynska \& Dorozynski, 2015). Menurut Blomstorm dan Kokko (2002), FDI merupakan penghubung untuk kemajuan teknologi di negara-negara tujuan. Artinya, negara tuan rumah menerima transfer teknologi dan efek spillover bagi tenaga kerja dari perusahaan multinasional. Sementara itu, Soltanpanah dan Karimi (2013) mengatakan bahwa FDI yang masuk ke sebuah negara secara kolektif berkontribusi kepada lingkungan makro negara tersebut melalui pajak. Hasil dari pajak dapat berupa infrastruktur untuk menunjang kegiatan ekonomi perusahaan atau dapat berupa infrastruktur yang menunjang peningkatan human capital, seperti infrasturktur untuk pendidikan dan kesehatan.

Arus FDI ke suatu negara dipengaruhi banyak faktor, diantaranya tingkat suku bunga, nilai tukar, kondisi sumber daya alam, dan kualitas human capital (termasuk produktivitas tenaga kerja) negara tujuan. Dengan kata lain, terdapat berbagai orientasi perusahaan multinasional untuk memasuki suatu negara diantaranya: resource seekers, market seekers, efficiency seekers, strategic assets seekers, escape investment dan support investment (Dunning, 1993). Dorozynska dan Dorozynski (2015) menemukan bahwa faktor penentu arus masuk FDI di Eropa Tengah dan Timur adalah kualitas modal manusia di negara tuan rumah.

Pada tingkat regional Asia, sub-regional Asia Selatan dan Asia Tenggara memgalami trend peningkatan arus masuk FDI yang berkelanjutan, sementara pertumbuhan FDI di Asia Timur lebih lambat. FDI yang masuk di sub-region Asia Timur bergeser lebih banyak ke kegiatan dengan nilai tambah intensif dan tinggi. China mempertahankan posisinya sebagai penerima FDI terbesar di wilayah Asia, diikuti oleh Singapura dan India. Arus masuk FDI ke China menurun pada tahun 2008 untuk pertama kalinya dalam tujuh tahun terakhir. Penurunan sebesar 4\% menjadi \$69 miliar terutama terjadi pada investasi jasa keuangan. Singapura mendapatkan FDI sebesar \$24 miliar dan India \$17 miliar yang setara dengan nilai penjumlahan dari arus masuk dalam tiga tahun terakhir. Sementara arus masuk menuju Indonesia hanya sebesar $\$ 4,9$ miliar.

\section{Gambar 1. Perkembangan Arus Masuk FDI di Beberapa Negara Asia (dalam miliar USD)}

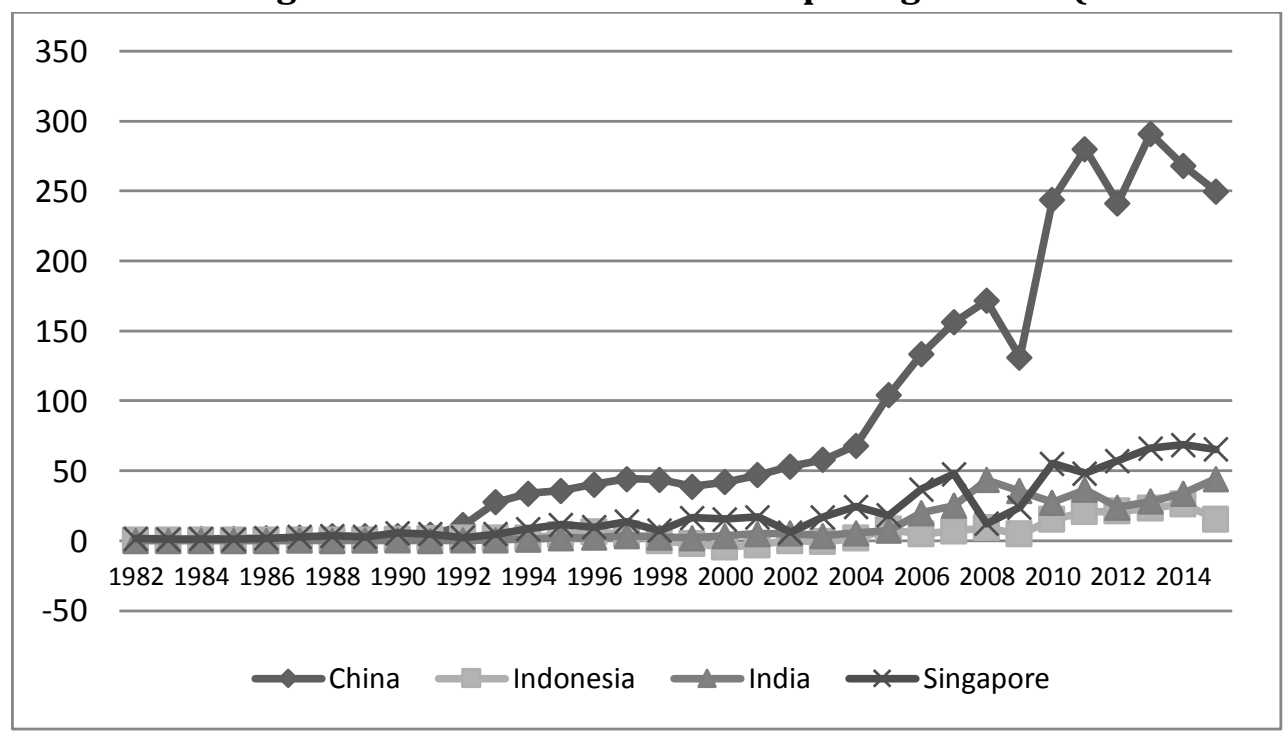

Sumber: World Bank (2016)

Jika dibandingkan dengan negara-negara Asia lain, seperti China, India, dan Singapura, arus masuk FDI ke Indonesia masih tertinggal (lihat Gambar 1). Pada awal tahun 1980-an, Indonesia masih dapat mengimbangi ketiga negara tersebut, tetapi sejak tahun 1998 Singapura dan China sudah meninggalkan Indonesia. Sementara sejak tahun 2006 terjadi lonjakan arus masuk FDI ke India. Walaupun terlihat pada tahun 2012 Indonesia dapat mengimbangi arus masuk FDI India, namun sekitar tahun 2013 kembali terjadi penurunan. Padahal, Indonesia 
memiliki potensi, karena negara ini memiliki karakteristik yang mirip dengan India, yaitu: jumlah penduduk besar, bahkan dengan tingkat pendapatan per kapita yang lebih tinggi (lihat Gambar 2), serta kekayaan sumber daya alam yang biasanya menjadi orientasi FDI.

Gambar 2. GDP per Kapita India dan Indonesia (dalam USD)

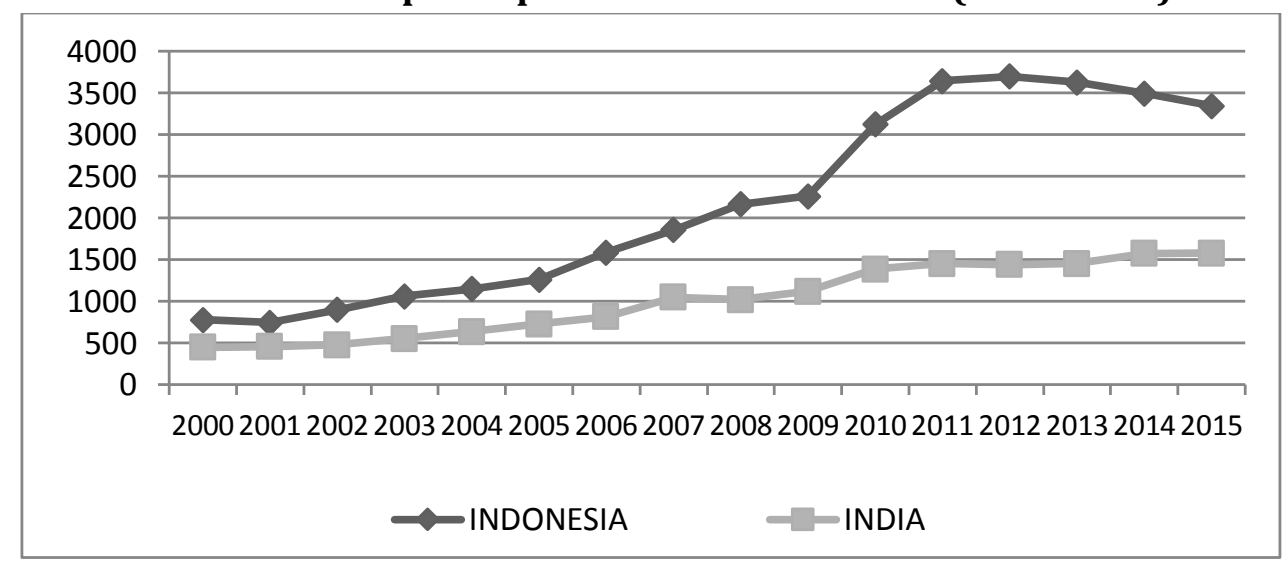

Sumber: World Bank (2016)

Indonesia dan India memiliki kemiripan tingkat pendapatan. Menurut World Bank (2016), Indonesia dan India termasuk kategori low-middle income. Namun dilihat pada Gambar 2, Indonesia memiliki GDP per kapita yang lebih tinggi dibandingkan India. Artinya, Indonesia memiliki potensi pasar besar karena daya beli yang sejalan dengan pendapatan. Indonesia dan India juga merupakan negara dengan jumlah penduduk besar di dunia, yakni India berada di peringkat kedua dan Indonesia keempat (World Bank, 2016). Jumlah penduduk besar menggambarkan pangsa pasar dan jumlah tenaga kerja yang besar. Hal tersebut merupakan modal penting yang akan memengaruhi perusahaan asing masuk sebuah negara.

FDI banyak memberikan manfaat terhadap negara tujuan, yaitu transfer teknologi dan efek spillover terhadap tenaga kerja. Di sisi lain, kualitas modal manusia negara tuan rumah merupakan daya tarik bagi FDI untuk menanamkan modalnya di negara tujuan. Oleh karena itu, diduga terdapat hubungan timbal balik antara FDI dan human capital. Indonesia dan India memiliki kemiripan karakteristik jumlah penduduk dan tingkat pendapatan. Namun, para investor asing lebih tertarik untuk menanamkan modalnya di India dibandingkan di Indonesia, ditunjukkan oleh perbedaan jumlah arus masuk FDI. Berdasarkan hal tersebut, diharapkan penelitian ini diharapkan dapat mengetahui pengaruh FDI pada human capital di negara tuan rumah (Indonesia dan India); dan sebaliknya. Selain itu, penulis ingin mengetahui orientasi FDI yang masuk ke India dan Indonesia sehingga terjadi perbedaan jumlah arus masuk di kedua negara tersebut.

\section{TINJAUAN PUSTAKA}

Teori Modal Manusia pertama kali diperkenalkan oleh Theodore W. Schultz pada tahun 1961 bahwa pengetahuan dan keterampilan yang didapatkan seseorang melalui pendidikan dan pelatihan adalah investasi terencana yang menghasilkan return. Pendidikan, pelatihan dan kesehatan merupakan bentuk investasi untuk membuka kesempatan bekerja bagi banyak individu. Schultz menambahkan ada lima cara pengembangan sumber daya manusia, yaitu: (1) fasilitas dan pelayanan kesehatan, mencakup semua pengeluaran yang memengaruhi harapan hidup, kekuatan dan stamina, tenaga kerja serta vitalitas rakyat; (2) latihan jabatan, termasuk 


\section{6 | Bina Ekonomi}

magang model lama yang diorganisasikan perusahaan; (3) pendidikan yang diorganisasikan secara formal pada tingkat dasar, menengah dan tinggi; (4) program studi bagi orang dewasa yang tidak diorganisasikan oleh perusahaan, termasuk program ekstensi khususnya pada pertanian; (5) migrasi perorangan dan keluarga untuk menyesuaikan diri dengan kerja yang selalu berubah (Schultz dalam Nafukho et al., 2004).

Human capital investment adalah upaya untuk meningkatkan pendapatan yang dihasilkan di kemudian hari dengan mengorbankan kesempatan untuk menikmati konsumsi hari ini. Seseorang dapat meningkatkan penghasilannya melalui pendidikan. Setiap tambahan satu tahun pendidikan, maka di satu sisi seseorang meningkatkan kemampuan kerja dan tingkat penghasilannya, di sisi lain seseorang menunda penerimaan penghasilan selama satu tahun yang bisa dia dapatkan jika bekerja (Tjiptoherijanto et al., 1982). Human capital investment yang dijelaskan oleh Tjiptoherijanto et al. (1982) dapat digambarkan ke dalam grafik seperti terlihat pada Gambar 3.

\section{Gambar 3. Grafik the Human Capital Investment}

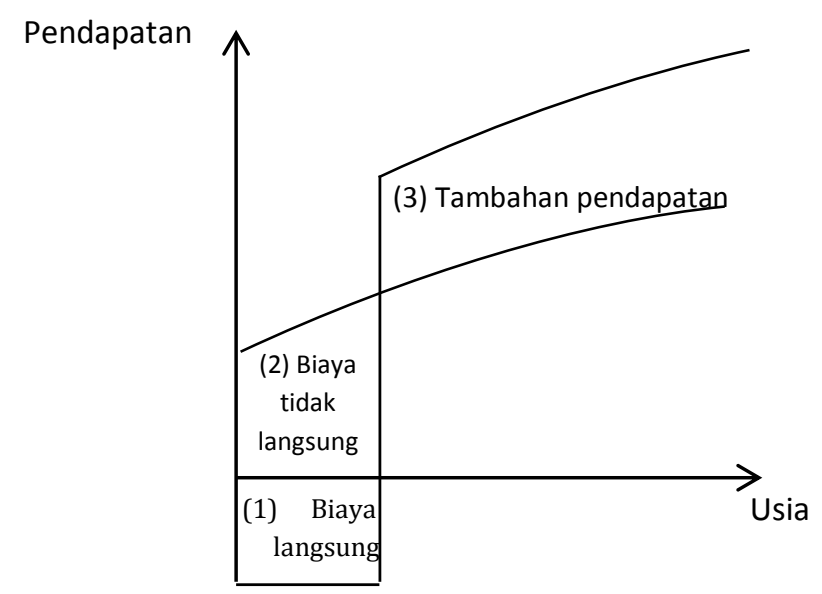

Sumber: McConnell et al. (2010)

Area (1) pada Gambar 3 menunjukkan biaya ketika seseorang melakukan human capital investment untuk melanjutkan pendidikan. Biaya langsung berupa biaya untuk menempuh pendidikan seperti, biaya kuliah, biaya membeli alat tulis, biaya transportasi selama kuliah dan lain-lain. Area (2) adalah biaya tidak langsung yang harus dibayarkan seseorang ketika lebih memilih melanjutkan pendidikan (human capital investment) daripada langsung bekerja. Biaya tidak langsung tersebut sebesar upah yang seharusnya diterima seseorang jika dia lebih memilih untuk bekerja. Area (3) merupakan jumlah tambahan pendapatan ketika seseorang telah melakukan human capital investment. Tambahan tersebut menggambarkan perbedaan pendapatan antara yang melakukan human capital investment dan tidak melakukannya. Perbedaan pendapatan tersebut juga dapat menggambarkan perbedaan produktivitas setelah melakukan human capital investment.

Todaro dan Smith (2006) membedakan modal manusia dengan sumber daya manusia. Modal manusia merupakan hasil dari pengeluaran di bidang pendidikan, penyediaan serta pengembangan program pelatihan kerja, dan pemeliharaan kesehatan. Sementara itu, sumber daya manusia adalah kuantitas dan kualitas angkatan kerja. Investasi modal manusia dapat meningkatkan kualitas sumber daya manusia yang memengaruhi kegiatan produksi dan pendapatan. Pendidikan formal, kejuruan, program latihan, dan pendidikan informal lainnya lebih efektif dalam menghasilkan tenaga terdidik apabila diikuti investasi berupa gedung, peralatan, 
dan material (buku, komputer, peralatan ilmiah, serta alat dan mesin pendidikan kejuruan). Selain itu, peningkatan kesehatan juga mampu meningkatkan kualitas sumber daya manusia menjadi lebih produktif sehingga dapat menghasilkan output optimal.

Tingkat human capital pada suatu negara dapat mencerminkan produktivitas dari tenaga kerja. Tenaga kerja dengan produktivitas tinggi menguntungkan perusahaan karena membuat produksi perusahaan lebih efisien. Maka dari itu, banyak perusahaan asing tertarik untuk menanamkan modalnya di negara lain yang memiliki kualitas human capital yang tinggi.

Faktor-faktor yang memengaruhi human capital adalah FDI, arus masuk FDI dapat memberikan dampak pada kualitas human capital melalui potensi transfer teknologi serta peningkatan kualitas fasilitas pendidikan dan kesehatan yang dapat disediakan pemerintah. Pengeluaran pemerintah di sektor kesehatan yang semakin besar berdampak pada pelayanan kesehatan masyarakat yang semakin baik. Peningkatan pengeluaran pemerintah untuk sektor kesehatan berpengaruh terhadap peningkatan kinerja sektor kesehatan. Pemerintah meningkatkan pelayanan kesehatan masyarakat dengan meningkatkan pelayanan di daerah terpencil dan meningkatkan fungsi puskesmas, menurunkan angka kematian ibu dan meningkatkan pengendalian penyakit-penyakit menular (Kementerian Keuangan, 2014). Peningkatan pelayanan tersebut bertujuan agar pembangunan manusia di Indonesia semakin merata. Selain kesehatan, pengeluaran pemerintah di sektor pendidikan dengan jumlah yang semakin besar akan meningkatkan kualitas human capital karena pengeluaran tersebut akan menunjang masyarakat untuk menempuh dan mendapatkan pendidikan yang lebih baik. Studi empiris yang dilakukan oleh Arifin et al. (2015) membuktikan teori Meier bahwa pengeluaran pemerintah yang besar pada sektor pendidikan akan berpengaruh terhadap perkembangan sektor Pendidikan ditunjukkan dengan peningkatan jumlah murid yang mampu menyelesaikan sekolahnya sampai ke tingkat yang lebih tinggi. Oleh karena itu, kualitas human capital di sebuah negara meningkat. Hal ini juga dijelaskan dalam Brata (2004) bahwa meningkatnya belanja pemerintah sektor pendidikan terbukti mampu mendorong peningkatan pertumbuhan ekonomi melalui peningkatan kualitas Indeks Pembangunan Manusia (IPM).

Pengertian FDI yang merujuk pada Krugman (seperti dikutip oleh Sarwedi, 2004) adalah arus modal internasional di mana perusahaan dari suatu negara mendirikan atau memperluas perusahaannya di negara lain. Implikasi FDI tidak hanya pemindahan sumber daya, tetapi juga terjadi pemberlakuan kontrol terhadap perusahaan di luar negeri. Menurut Kurniati et al. (2007), FDI dapat berupa greenfield, yaitu membangun unit produksi yang baru dan akuisisi atau investasi dengan membeli sebagian kepemilikan perusahaan yang sudah ada sebelumnya. Greenfield adalah investasi riil dalam bentuk pabrik, barang modal, lahan, dan inventori yang melibatkan modal dan manajemen, di mana investor mempertahankan kontrol dalam penggunaan modal (Salvatore, 2013). Sementara itu, FDI dengan membeli sebagian kepemilikian perusahaan didefinisikan sebagai bentuk international non-debt-creating, di mana investor terlibat dalam saham ekuitas yang lebih dari sepuluh persen (jika mengacu pada definisi oleh OECD) dan memiliki kekuatan pengelolaan keputusan atau kontrol kepemilikan pada perusahaan asing (Mello \& Fukusaku, 2000).

FDI penting bagi kelangsungan pembangunaan jangka panjang sebab melibatkan pembangunan investasi fisik. FDI juga membuka pasar dan jalur pemasaran bagi perusahaan, fasilitas produksi yang lebih murah dan akses pada teknologi, produk, keterampilan, dan pendanaan. FDI bermula saat sebuah perusahaan dari suatu negara membeli saham sebuah perusahaan di negara lain ataupun mendirikan perusahaan di negara lain. Dengan begitu, 


\section{8 | Bina Ekonomi}

perusahaan yang ada di negara asal (home country) bisa memengaruhi perusahaan yang ada di negara tujuan investasi (host country) baik sebagian atau seluruhnya. Selain alih teknologi, FDI juga mendorong kompetisi di pasar domestik. Perusahaan multinasional yang memberikan pelatihan bagi karyawan akan berkontribusi terhadap pembangunan sumber daya manusia di host country dan laba yang dihasilkan juga berkontribusi terhadap pajak pendapatan (Razin \& Sadka, 2000).

Dunning (1993) mengemukakan enam tujuan perusahaan multinasional memasuki suatu negara, yaitu resource seekers, market seekers, efficiency seekers, strategic assets seeker, escape investment, dan support investment. Berdasarkan resource seekers, jenis sumber daya yang dicari oleh perusahaan multinasional adalah sumber daya alam, tenaga kerja melimpah, tenaga kerja yang memiliki kemampuan teknologi, organisasi dan manajemen, tenaga kerja dengan motivasi bekerja, serta murah. Pada awalnya, FDI masuk ke negara berkembang terdorong oleh sumber daya alam melimpah dan tenaga kerja skill rendah dan murah. Namun kemudian, Singapura, Korea Selatan, Taiwan dan India mampu menarik investor yang berorientasi pada teknologi tinggi dan tenaga kerja dengan skill tinggi. Market seekers adalah investasi yang dilakukan untuk mempertahankan pasar yang semula menjadi target ekspor tetapi menurun karena berbagai halangan perdagangan atau untuk mencari pasar baru. Alasan efficiency seekers adalah untuk mendapatkan economies of scale dan economies of scope serta diversifikasi risiko usaha. Strategic assets seeker melakukan akuisisi aset asing dalam industri sejenis atau berbeda untuk menunjang daya kompetisi di masa mendatang atau mengahalangi pesaing untuk memperoleh kekuatan pasar. Sementara itu, escape investment adalah untuk menghindari perturan-peraturan yang merugikan atau restrictive di negaranya sendiri. Support investment merupakan tujuan investasi untuk mendukung aktivitas perusahaan atau cabang di negara lain.

Besaran FDI ditentukan oleh beberapa faktor. Pertama, infrastruktur merujuk pada sistem transportasi, pengairan, drainase, bangunan dan fasilitas publik lain yang dibutuhkan untuk memenuhi kebutuhan dasar manusia dalam lingkup sosial dan ekonomi. Ketersediaan infrastruktur yang baik mendorong efisiensi biaya. Oleh karena itu, peningkatan infrastruktur dapat mendorong FDI masuk karena infrastruktur menunjang kegiatan bisnis. Dalam penelitian ini infrastruktur dicerminkan oleh variabel Gross Capital Formation Index (GCI). Semakin baik infrastruktur sebuah negara maka semakin besar FDI yang masuk.

Variabel kedua yang diduga memengaruhi FDI adalah pertumbuhan ekonomi dicerminkan melalui pertumbuhan GDP. Kurniati et al. (2007) menyatakan bahwa peningkatan pertumbuhan ekonomi di suatu negara dapat meningkatkan minat investor dalam menanamkan FDI. Pertumbuhan GDP menunjukkan adanya peningkatan ukuran pasar sehingga negara-negara yang mengalami pertumbuhan GDP dapat menjadi wilayah basis penjualan.

Risiko merupakan faktor penting penentu masuknya FDI. Risiko sebuah negara dibangun dari beberapa aspek, seperti stabilitas politik, efektivitas pemerintahan dalam menerapkan kebijakan, kualitas kebijakan, pengawasan terhadap korupsi, keamanan negara, dan aturan hukum. Semakin besar risiko, maka semakin kecil kemungkinan FDI masuk ke sebuah negara. Hal tersebut terjadi karena semakin besar ketidakpastian yang dihadapi investor. Selain itu, kebijakan terkait investasi merupakan salah satu faktor kunci FDI menanamkan modalnya di sebuah negara (WIR, 2010). Dunning (1993) menjelaskan bahwa kebijakan terkait investasi menjadi salah satu orientasi perusahaan asing melakukan escape investment, yaitu peraturan yang ketat terkait bisnis di negara asal sehingga perusahaan mencari negara dengan kebijakan investasi yang lebih longgar. Berdasarkan laporan World Bank Group (2014), kemudahan dalam melakukan berbisnis terdiri atas tiga komponen diantaranya tingkat pajak, lama waktu untuk mendapatkan izin 
memulai bisnis dan mendirikan bangunan, dan kualitas dalam penegakan kontrak bisnis. Jika kebijakan terkait investasi semakin membaik maka FDI yang masuk semakin besar.

Secara ringkas kerangka pemikiran penelitian ini adalah sebagai berikut. FDI yang masuk ke sebuah negara meningkatkan tingkat human capital. FDI memengaruhi kualitas human capital dengan capital yang dibawa, transfer teknologi, spillover effect dan meningkatkan pendapatan pemerintah melalui pajak yang dapat dipakai untuk belanja pemerintah (misalkan: pengeluaran pemerintah di sektor pendidikan dan kesehatan). Selain FDI, human capital juga dipengaruhi oleh beberapa upaya pemerintah seperti investasi di sektor pendidikan dan juga investasi di sektor kesehatan. Peningkatan kualitas di sektor pendidikan dan sektor kesehatan tersebut berdampak pada peningkatan kualitas human capital.

\section{Gambar 3. Hubungan Keterkaitan Antar Variabel yang Digunakan dalam Penelitian}

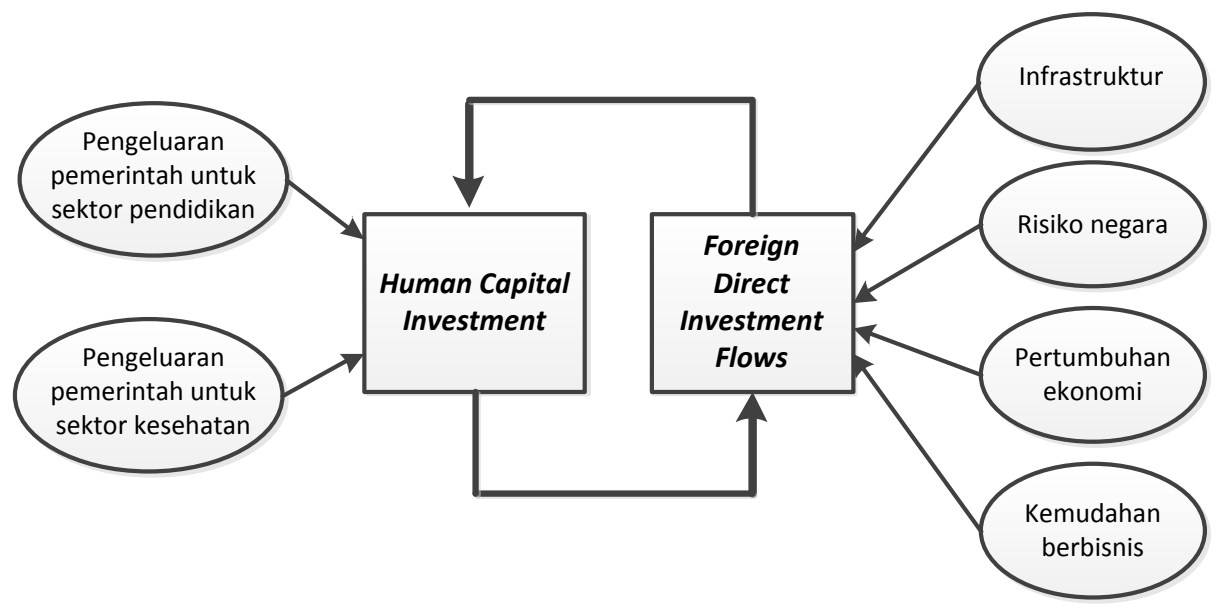

Sumber: Hasil olahan penulis

Di sisi lain, human capital memengaruhi arus masuk FDI karena memberikan daya tarik bagi perusahaan asing. Peningkatan kualitas human capital akan meningkatkan arus masuk FDI ke sebuah negara, karena tingkat human capital menggambarkan produktivitas tenaga kerja. Hal tersebut merupakan salah satu orientasi dari perusahaan karena dapat mewujudkan efisiensi produksi. Selain tingkat human capital, banyak juga motif yang memengaruhi arus masuk FDI ke sebuah negara diantaranya, pertumbuhan ekonomi, infrastruktur, tingkat risiko sebuah negara dan kemudahan dalam melakukan bisnis. Variabel yang mencerminkan kemudahan berbisnis adalah Index Doing Business (IDB). Variabel IDB dibentuk dari beberapa variabel diantaranya tingkat pajak, lama waktu untuk mendapatkan izin memulai bisnis dan mendirikan bangunan, dan kualitas dalam penegakan kontrak bisnis. Nilai IDB yang semakin kecil berarti semakin mudah dalam melakukan bisnis. Maka dari itu, semakin kecil IDB akan berdampak pada peningkatan FDI masuk. Kerangka pemikiran penelitian seperti yang dipaparkan di atas dapat dilihat di Gambar 3 .

\section{METODE DAN OBJEK PENELITIAN}

Studi empiris dilakukan untuk menganalisis hubungan timbal balik antara arus masuk Foreign Direct Investment (FDI) dan human capital di Indonesia dan India. Faktor-faktor yang diperkirakan memengaruhi arus masuk FDI adalah human capital, infrastruktur, pertumbuhan ekonomi, risiko negara, dan kemudahan berbisnis. Sementara itu, diduga human capital dipengaruhi oleh FDI, pengeluaran pemerintah di sektor pendidikan, dan pengeluaran 


\section{0 | Bina Ekonomi}

pemerintah di sektor kesehatan. Data time series tahunan dari tahun 2000 sampai 2015 dari dua negara yaitu Indonesia dan India digunakan dalam penelitian. Data beserta sumbernya ditampilkan pada Tabel 1.

Tabel 1. Data dan Sumber Data

\begin{tabular}{|c|c|c|c|c|}
\hline Negara & Jenis Variabel & \multicolumn{2}{|c|}{ Variabel (Satuan) } & Sumber Data \\
\hline \multirow{8}{*}{$\begin{array}{l}\text { Indonesia } \\
\text { dan India }\end{array}$} & Dependen & HDI & Human Capital & UNDP \\
\hline & Dependen & FDI (miliar US\$) & Arus masuk FDI & World Bank \\
\hline & Independen & EXPedu (\%) & $\begin{array}{l}\text { Pengeluaran } \\
\text { pemerintah untuk } \\
\text { sektor pendidikan }\end{array}$ & World Bank \\
\hline & Independen & EXPhealth (\%) & Pengeluaran & World Bank \\
\hline & Independen & $\begin{array}{c}\text { GCF (miliar } \\
\text { US\$) }\end{array}$ & Infrastruktur & World Bank \\
\hline & Independen & GDPgrowth (\%) & Pertumbuhan Ekonomi & World Bank \\
\hline & Independen & IDB & Kemudahan berbisnis & J. Doing Business \\
\hline & Independen & CR & Risiko Negara & PRS \\
\hline
\end{tabular}

Sumber: Hasil olahan penulis

Hubungan antara human capital dan FDI dilihat dengan menggunakan metode persamaan regresi two stage least square (TSLS), yaitu model regresi yang jumlahnya lebih dari satu persamaan di mana variabel independen pada satu persamaan dapat menjadi variabel dependen pada persamaan lain dan masing-masing variabel dependen dijelaskan oleh variabel independen yang sama atau berbeda. Beberapa variabel dilatarbelakangi oleh usaha yang dilakukan sebelum pertumbuhan terjadi (lag). TSLS harus menerapkan order condition: $\mathbf{m}-\mathbf{1} \leq \mathbf{K}-\mathbf{k}$; di mana $\mathbf{m}$ adalah jumlah variabel dependen dalam setiap persamaan, $\mathrm{K}$ adalah jumlah seluruh variabel independen dalam seluruh persamaan dan $\mathrm{k}$ adalah jumlah variabel independen dalam setiap persamaan. Pada persamaan pertama, variabel human development index (HDI) sebagai variabel dependen yang dipengaruhi oleh FDI, Expenditure on Education, dan Expenditure on Health. Pada persamaan kedua, variabel FDI sebagai variabel dependen yang dipengaruhi oleh human development index, gross capital formation (GCF), country risk (CR), GDP growth, dan index doing business (IDB). Kedua persamaan untuk masing-masing negara dituliskan berikut:

a. India

$$
\begin{aligned}
& H D I_{t}=\hat{\alpha}_{0}+\hat{\alpha}_{1} F D I_{t}+\hat{\alpha}_{2} D(\text { ExponEdu })_{t}+\hat{\alpha}_{3} D(\text { ExponHealth })_{t}+\hat{v}_{t} \\
& F D I_{t}=\hat{\beta}_{0}+\hat{\beta}_{1} H D I_{t}+\hat{\beta}_{2} C R_{t}+\hat{\beta}_{3} D(G C F)_{t}+\hat{\beta}_{4} G D \text { Pgrowth }_{t}+\hat{\beta}_{5} I D B_{t}+\hat{v}_{t}
\end{aligned}
$$

\section{b. Indonesia}

$$
\begin{aligned}
& H D I_{t}=\hat{\alpha}_{4}+\hat{\alpha}_{5} F D I_{t}+\hat{\alpha}_{6} \text { ExponEdu }_{t-1}+\hat{\alpha}_{7} \text { ExponHealth }_{t-1}+\hat{v}_{t} \\
& F D I_{t}=\hat{\beta}_{6}+\hat{\beta}_{7} H D I_{t}+\hat{\beta}_{8} C R_{t}+\hat{\beta}_{9} D(G C F)_{t}+\hat{\beta}_{10} \text { GDPgrowth }_{t}+\hat{\beta}_{11} I D B_{t}+\hat{v}_{t}
\end{aligned}
$$

Keterangan:

$$
\begin{array}{lll}
\text { HDI } & : \text { tingkat kualitas human capital } & \\
\text { EXPonEdu } & : \text { persentase pengeluaran untuk pendidikan terhadap pengeluaran } \\
& \text { pemerintah } & \\
\text { D(EXPonEdu }) & : \begin{array}{l}
\text { perubahan persentase pengeluaran untuk pendidikan terhadap } \\
\text { pengeluaran pemerintah dari tahun sebelumnya }
\end{array} \\
\text { ExponHealth } & : \begin{array}{l}
\text { persentase pengeluaran untuk kesehatan terhadap pengeluaran } \\
\text { pemerintah }
\end{array}
\end{array}
$$




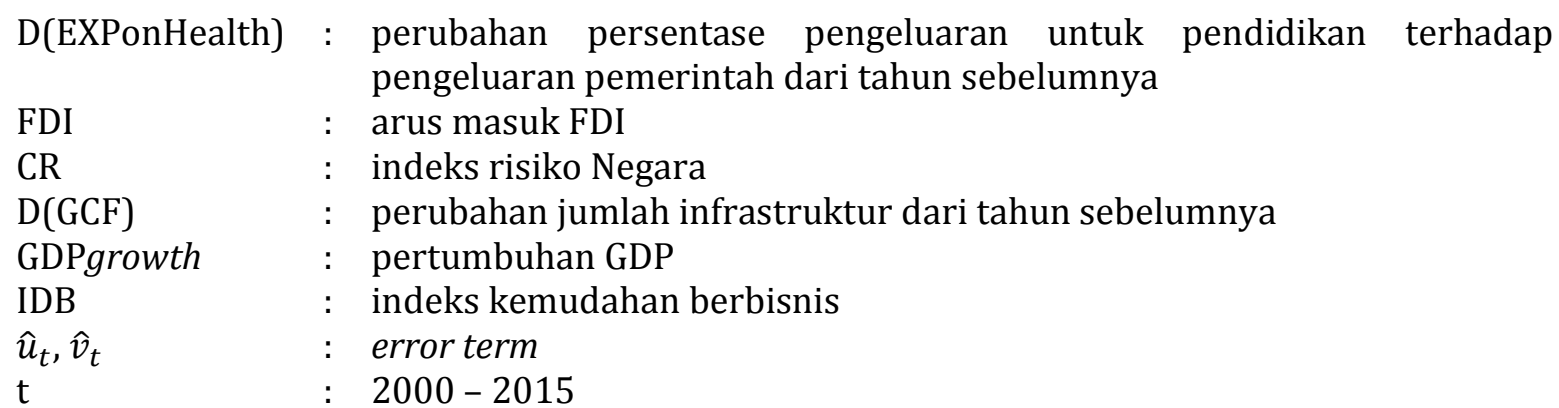

Human Development Index (HDI) menjelaskan bagaimana penduduk dapat mengakses hasil pembangunan dalam memperoleh pendapatan, kesehatan dan pendidikan. Bagi Indonesia, HDI merupakan ukuran strategis karena selain sebagai ukuran kinerja pemerintah, HDI juga digunakan sebagai salah satu alokator penentuan Dana Alokasi Umum (DAU). Data pada Lampiran 1 menunjukkan, secara keseluruhan HDI Indonesia lebih baik dibandingkan India. India dan Indonesia juga berhasil meningkatkan HDI dari tahun ke tahun. Namun dalam beberapa tahun terakhir, India berhasil tumbuh lebih cepat sehingga gap HDI Indonesia dan India semakin kecil. Hal tersebut menggambarkan keberhasilan pemerintah India dalam pengalokasian pengeluaran pemerintah secara efektif.

Variabel Expenditure on education adalah total pengeluaran pemerintah untuk sektor pendidikan yang dinyatakan sebagai persentase dari total pengeluaran pemerintah pada tahun tertentu. Pengeluaran publik untuk pendidikan meliputi pengeluaran pemerintah pada lembagalembaga pendidikan baik negeri maupun swasta, administrasi pendidikan, dan subsidi untuk entitas swasta (siswa atau rumah tangga dan entitas swasta lainnya) (World Bank, 2013). Data pada Lampiran 1 memperlihatkan bahwa India cenderung mengeluarkan anggaran yang besar untuk pendidikan sejak awal tahun 2000 dan hingga tahun 2009; namun selanjutnya berfluktuasi bahkan cenderung menurun. Sementara Indonesia cenderung berbanding terbalik dengan India. Pada tahun 2000 Indonesia masih menganggarkan dana untuk sektor pendidikan dengan persentase yang kecil, namun hingga tahun 2015 trend persentase anggarannya terus meningkat.

Expenditure on health sangat dibutuhkan dalam meningkatkan human capital investment. Expenditure on health diharapkan dapat meningkatkan kualitas sumber daya manusia. Jika sumber daya memiliki tingkat kesehatan yang baik maka di harapkan para sumber daya manusia mampu memaksimalkan produktivitasnya dalam bekerja. Indikator pengeluaran pemerintah disektor kesehatan dihitung dari total pengeluaran pemerintah untuk kesehatan dibagi dengan total pengeluaran pemerintah dikali 100\%. Data pada Lampiran 1 menunjukkan bahwa, sejak tahun 2000 hingga 2015 terjadi trend peningkatan terhadap persentase anggaran untuk sektor kesehatan di Indonesia. Sementara persentase anggaran pemerintah untuk sektor kesehatan di India mengalami fluktuasi, namun sejak tahun 2010 terus mengalami peningkatan hingga tahun 2015 .

Data pada Lampiran 1 untuk FDI memperlihatkan bahwa arus masuk FDI ke Indonesia sempat berada dibawah nol. Hal tersebut disebabkan oleh pasca krisis yang terjadi di Indonesia pada tahun 1998 sehingga memengaruhi ke lingkungan bisnis. Setelah itu terjadi trend peningkatan terhadap arus masuk FDI ke Indonesia hingga tahun 2015. Walaupun sempat terjadi penurunan pada beberapa tahun, seperti pada tahun 2008 dan 2015. Sementara di India juga terjadi trend peningkatan arus masuk FDI. Bahkan dari tahun 2005 hingga 2008 terjadi lonjakan yang begitu besar dari arus masuk FDI di India. Walaupun begitu, terjadi juga beberapa kali penurunan seperti pada tahun 2008 dan 2011. Penurunan yang terjadi pada tahun 2008 juga 


\section{2 | Bina Ekonomi}

dampak dari krisis yang terjadi di Amerika. Hal tersebut memperlihatkan bahwa lingkungan bisnis Indonesia dan India dipengaruhi juga oleh negara lain khususnya negara mitra dalam berbisnis.

Country Risk Index (CR) merupakan data tahunan yang terbitkan oleh Political Risk Services International Country Risk Guide (PRS). Data tesebut menggambarkan risiko sebuah negara dari bebepa indikator diantaranya stabilitas politik, efektivitas pemerintahan dalam menerapkan kebijakan, kualitas kebijakan, pengawasan terhadap korupsi, keamanan negara, dan aturan hukum yang berlaku. Dengan semakin tinggi nilai CR maka negara tersebut memiliki risiko yang semakin kecil yang berarti semakin aman untuk tinggal atau berbisnis di negara tersebut. Lampiran 1 menunjukkan, Indonesia dan India memiliki rata-rata CR yang cenderung tetap pada nilai 0,6 untuk Indonesia dan 0,65 untuk India pada periode pengamatan (tahun 2000 hingga 2015). Indonesia mengalami perbaikan nilai CR pasca krisis tahun 1998, namun sejak tahun 2011 hingga tahun 2015 nilai CR Indonesia cenderung menurun. Sementara nilai CR India cenderung terus meningkat sejak tahun 2000 hingga 2015 yang hampir mencapai 0,7. Dari Lampiran 1 terlihat bahwa Indonesia lebih berisiko dibandingkan dengan India.

Gross capital formation (GCF) adalah pembentukan modal tetap bruto meliputi perbaikan lahan pagar, selokan, saluran air, pembelian pabrik, mesin, peralatan, pembangunan jalan, jalur kereta api. Di dalamnya termasuk juga sekolah, kantor, rumah sakit, perumahan, dan bangunan industri. Akuisisi bersih barang berharga juga dianggap pembentukan modal (World Bank, 2013). Umumnya, semakin tinggi pembentukan modal bruto suatu negara, maka akan semakin cepat pertumbuhan ekonomi negara tersebut secara agregat. Dari Lampiran 1 dapat dilihat bahwa trend peningkatan di Indonesia dan India sejak tahun 2000. Perbedaannya India memiliki nilai GCF yang lebih besar daripada Indonesia sejak tahun 2000. Selain itu, peningkatan GCF di India lebih besar setiap tahunnya sehingga pada tahun 2015 India memiliki nilai GCF hingga lebih dari dua kali lipat dibandingkan Indonesia. Namun hal tersebut tidak dapat menunjukkan bahwa kondisi infrastruktur di India lebih baik daripada di Indonesia, karena India memiliki luas wilayah negara yang lebih luas dan jumlah populasi yang lebih banyak dibandingkan Indonesia.

Pertumbuhan Gross Domestic Product (GDP growth) merupakan proxy yang dapat menggambarkan pertumbuhan ekonomi di suatu negara/wilayah. GDP growth menunjukkan perubahan jumlah nilai produksi yang terjadi di sebuah negara dari tahun ke tahun. Lampiran 1 memperlihatkan, pertumbuhan GDP di Indonesia dan India berfluktuasi. Namun India memiliki trend pertumbuhan yang lebih baik dibandingkan Indonesia. Walaupun beberapa tahun pertumbuhan yang terjadi di Indonesia lebih tinggi daripada di India seperti pada tahun 2000, 2002, dan 2008.

Index doing business (IDB) merupakan variabel yang penulis rumuskan sendiri melalui tiga komponen. IDB dibentuk dari komponen diantaranya tingkat pajak, lama waktu untuk mendapatkan izin memulai bisnis dan mendirikan bangunan, dan kualitas dalam penegakan kontrak bisnis. Hasil dari pengolahan data tersebut, menunjukkan semakin kecil nilai IDB artinya kebijakan untuk menjalankan bisnis disebuah negara semakin mudah. Data pada Lampiran 1 menunjukkan bahwa Indonesia dan India sama-sama makin mempermudah bagi siapapun yang akan melakukan bisnis. Kebijakan mempermudah perusahaan dalam menjalankan bisnis tersebut menunjukkan bahwa keduanya sama-sama menginginkan semakin banyak bisnis di negara masing-masing. Hal tersebut seharusnya dapat menarik minat investor untuk menanamkan modalnya di Indonesia dan India. 


\section{HASIL DAN PEMBAHASAN}

Hasil regresi untuk Indonesia ditampilkan oleh Tabel 2 dan untuk India ditunjukkan oleh Tabel 3.

Tabel 2. Hasil Regresi untuk Data Indonesia

\begin{tabular}{cllll}
\hline Negara & INDONESIA & & & \\
\hline Variabel dependen & HDI & & & \\
\hline Variabel & Koefisien & Std. Error & t-Statistic & Prob \\
\hline C & 0,558036 & 0,021221 & 26,29627 & 0,0000 \\
FDI & 0,001686 & 0,000293 & 5,753377 & 0,0001 \\
ExponEdu $_{\mathrm{t}-1}$ & 0,002429 & 0,001308 & 1,856613 & 0,0903 \\
ExponHealth $_{\mathrm{t}-1}$ & 0,015560 & 0,009153 & 1,699933 & 0,1172 \\
\hline R-Squared & 0,950591 & & & \\
F-Statistic & 71,69136 & & & \\
Prob(F-Statistic) & 0,000000 & & & \\
Durbin-Watson Stat & 1,377724 & & & \\
\hline & & & & \\
\hline Variabel dependen & FDI & & & \\
\hline Variabel & Koefisien & Std. Error & t-Statistic & Prob \\
\hline HDI & 51,79405 & 22,27935 & 2,324756 & 0,0424 \\
CR & $-70,66506$ & 31,21177 & $-2,264052$ & 0,0470 \\
D(GCF) & $-0,093387$ & 0,054321 & $-1,719178$ & 0,1163 \\
GDPgrowth & 5,448602 & 2,258882 & 2,412079 & 0,0366 \\
IDB & $-0,153574$ & 0,020922 & $-7,340410$ & 0,0000 \\
\hline R-Squared & 0,874138 & & & \\
Durbin-Watson Stat & 2,263483 & & & \\
\hline
\end{tabular}

Sumber: Hasil olahan penulis

Tabel 3. Hasil Regresi untuk Data India

\begin{tabular}{cllll}
\hline Negara & INDIA & & & \\
\hline Variabel dependen & HDI & & & \\
\hline Variabel & Koefisien & Std. Error & t-Statistic & Prob \\
\hline C & 0,516990 & 0,009412 & 54,93021 & 0,0000 \\
FDI & 0,002084 & 0,000391 & 5,322407 & 0,0002 \\
D(ExponEdu) & 0,012521 & 0,005240 & 2,389433 & 0,0359 \\
D(ExponHealth) & 0,035440 & 0,015972 & 2,218893 & 0,0485 \\
\hline R-Squared & 0,903422 & & & \\
F-Statistic & 34,90504 & & & \\
Prob(F-Statistic) & 0,000006 & & & \\
Durbin-Watson Stat & 1,507894 & & & \\
& & & & \\
\hline Variabel dependen & FDI & & & \\
\hline Variabel & Koefisien & Std. Error & t-Statistic & Prob \\
\hline HDI & $-29,84417$ & 76,92218 & $-0,387979$ & 0,7062 \\
CR & 128,4319 & 78,95104 & 1,626729 & 0,1349 \\
D(GCF) & 0,001847 & 0,038700 & 0,047719 & 0,9629 \\
GDPgrowth & $-2,423414$ & 1,368476 & $-1,770885$ & 0,1070 \\
IDB & $-0,330840$ & 0,070766 & $-4,675105$ & 0,0009 \\
\hline R-Squared & 0,871547 & & & \\
Durbin-Watson Stat & 1,691970 & & & \\
\hline
\end{tabular}

Sumber: Hasil olahan penulis 


\section{4 | Bina Ekonomi}

Uji multikolinearitas dilakukan untuk melihat hubungan linear atau korelasi yang tinggi antara variabel independen. Jika koefisien korelasi antara masing-masing variabel independen lebih dari 0,8, maka terjadi multikolinearitas. Berdasarkan hasil uji multikolinearitas, diketahui bahwa koefisien korelasi di antara seluruh variabel independen dari dua persamaan memiliki nilai dibawah 0,8 atau $80 \%$, mengindikasikan bahwa tidak ada multikolinearitas.

Selain itu, uji autokorelasi dilakukan untuk mengetahui keberadaan korelasi residual pada satu observasi dengan residual observasi lain yang diurutkan menurut waktu. Dari hasil uji Durbin-Watson (DW) pada persamaan regresi untuk Indonesia, diperoleh nilai DW-stat yang berada pada daerah ragu-ragu (inconclusive). Sementara itu, dari hasil uji untuk persamaan India, diperoleh nilai DW-stat yang mengindikasikan tidak terdapat autokorelasi positif atau negatif. Hal ini menunjukkan bahwa tidak terdapat penyimpangan pada kedua persamaan tersebut.

Uji-t digunakan untuk mengetahui apakah masing-masing variabel bebas mempunyai pengaruh yang signifikan terhadap variabel terikat.

- $H_{0}: \beta k=0$, artinya secara parsial pengaruh variabel independen terhadap variabel dependen tidak signifikan.

- $H_{1}: \beta k \neq 0$, artinya secara parsial pengaruh variabel independen terhadap variabel dependen signifikan.

Jika nilai t-statistik > t-tabel, maka $\mathrm{H}_{0}$ ditolak dan $\mathrm{H}_{1}$ diterima, dengan kata lain terdapat pengaruh antara variabel dependen dan variabel independen. Sebaliknya jika t-statistik < $\mathrm{t}$-tabel, maka $\mathrm{H}_{0}$ diterima dan $\mathrm{H}_{1}$ ditolak, yang artinya tidak terdapat hubungan antara variabel dependen dan variabel independen. Hasil t-tabel pada $\alpha=1 \%, \alpha=5 \%$, dan $\alpha=10 \%$ untuk menguji koefisien regresi parsial disajikan oleh Tabel 4.

Tabel 4. Hasil t-tabel untuk Analisis Regresi Parsial

\begin{tabular}{ccccccc}
\hline & \multicolumn{3}{c}{ Persamaan (1) Var. Dep.: HDI } & \multicolumn{3}{c}{ Persamaan (1) Var. Dep.: HDI } \\
\hline & $\boldsymbol{\alpha}=\mathbf{1 \%}$ & $\boldsymbol{\alpha}=\mathbf{5 \%}$ & $\boldsymbol{\alpha = 1 0 \%}$ & $\boldsymbol{\alpha = 1 \%}$ & $\boldsymbol{\alpha}=\mathbf{5 \%}$ & $\boldsymbol{\alpha = 1 0 \%}$ \\
\hline t-tabel & 3,055 & 2,179 & 1,782 & 3,169 & 2,228 & 1,812 \\
\hline
\end{tabular}

Sumber: Hasil olahan penulis

Hasil regresi persamaan pertama negara Indonesia memperlihatkan nilai t-stat koefisien variabel FDI sebesar 5,75. Nilai t-stat 5,75 lebih besar dibandingkan nilai t-tabel 3,055. Oleh karena itu tolak $\mathrm{H}_{0}$ atau dengan kata lain koefisien variabel FDI signifikan pada $\alpha=1 \%$. Nilai tstat koefisien variabel expenditure on education (Exponedu) sebesar 1,856 yang lebih besar dari ttabel 1,782 sehingga koefisien variabel expenditure on education (Exponedu) signifikan pada $\alpha=10 \%$. Nilai t-stat koefisien variabel expenditure on health (Exponhealth) sebesar 1,699 lebih besar dari nilai t-tabel 1,782 sehingga koefisien variabel expenditure on health (Exponhealth) tidak signifikan bahkan pada $\alpha=10 \%$.

Hasil regresi persamaan kedua untuk Indonesia memperlihatkan nilai t-stat koefisien variabel HDI sebesar 2,324 yang lebih besar dibandingkan nilai t-tabel 2,228 sehingga koefisien variabel HDI signifikan pada $\alpha=5 \%$. Nilai t-stat koefisien variabel CR sebesar $|-2,264|$ yang lebih besar dari t-tabel 2,228 sehingga koefisien variabel CR signifikan pada $\alpha=5 \%$. Nilai t-stat koefisien variabel GCF sebesar |-1,7191| yang lebih kecil dari nilai t-tabel 1,812 sehingga koefisien variabel GCF tidak signifikan pada $\alpha=10 \%$. Nilai t-stat koefisien variabel GDP growth sebesar 2,412 yang lebih besar dibandingkan nilai t-tabel 2,228 sehingga koefisien variabel GDP growth signifikan pada $\alpha=5 \%$. Nilai t-stat koefisien variabel IDB sebesar $|-7,340|$ yang lebih besar dibandingkan 
nilai t-tabel 3,169 sehingga koefisien variabel IDB signifikan pada $\alpha=1 \%$.

Hasil regresi persamaan pertama untuk India memperlihatkan nilai t-stat koefisien variabel FDI sebesar 5,322. Nilai t-stat 5,322 lebih besar dibandingkan nilai t-tabel 3,055. Oleh karena itu tolak $\mathrm{H}_{0}$ atau dengan kata lain koefisien variabel FDI signifikan pada $\alpha=1 \%$. Nilai tstat koefisien variabel expenditure on education (Exponedu) sebesar 2,389 yang lebih besar dari ttabel 2,179 sehingga koefisien variabel expenditure on education (Exponedu) signifikan pada $\alpha=5 \%$. Nilai t-stat koefisien variabel expenditure on health (Exponhealth) sebesar 2,218 yang lebih besar dari nilai t-tabel 2,179 sehingga koefisien variabel expenditure on health (Exponhealth) signifikan pada $\alpha=5 \%$.

Hasil regresi persamaan kedua untuk India memperlihatkan nilai t-stat koefisien variabel HDI sebesar $|-0,3879|$ yang lebih kecil dibandingkan nilai t-tabel 1,812. Oleh karena itu terima $\mathrm{H}_{0}$ atau dengan kata lain koefisien variabel HDI tidak signifikan pada $\alpha=10 \%$. Nilai t-stat koefisien variabel CR sebesar 1,6267 yang lebih kecil dari t-tabel 1,812 sehingga koefisien variabel CR tidak signifikan pada $\alpha=10 \%$. Nilai t-stat koefisien variabel GCF sebesar 0,0477 lebih kecil dari nilai ttabel 1,812 sehingga koefisien variabel GCF tidak signifikan pada $\alpha=10 \%$. Nilai t-stat koefisien variabel GDP growth sebesar |-1,7708|lebih kecil dibandingkan nilai t-tabel 1,812 sehingga koefisien variabel GDP growth tidak signifikan pada $\alpha=10 \%$. Nilai t-stat koefisien variabel IDB sebesar $|-4,6750|$ lebih besar dibandingkan nilai t-tabel 3,169 sehingga koefisien variabel IDB signifikan pada $\alpha=1 \%$.

Koefisien determinasi $\left(\mathrm{R}^{2}\right)$ digunakan untuk mengetahui persentase variasi variabel dependen dapat dijelaskan oleh variabel independen. Angka koefisien determinasi yang didapat untuk persamaan pertama untuk India adalah 0,903, artinya variabel human development index diterangkan oleh FDI inflows, expenditure on education, dan expenditure on health sebesar 90,3\% dan sisanya sebesar 9,7\% dijelaskan oleh faktor lainnya yang tidak termasuk ke dalam penelitian. Angka koefisien determinasi yang didapat dalam persamaan kedua untuk India adalah sebesar 0,871 yang diartikan bahwa variabel FDI inflows diterangkan oleh human development index, country risk, gross capital formation, dan index doing business sebesar $87,1 \%$ dan sisanya sebesar $12,9 \%$ dijelaskan oleh faktor lainnya yang tidak termasuk ke dalam penelitian.

Angka koefisien determinasi yang didapat untuk persamaan pertama negara Indonesia adalah sebesar 0,95, artinya variabel human development index diterangkan oleh FDI inflows, expenditure on education, dan expenditure on health sebesar $95 \%$ dan sisanya sebesar $5 \%$ dijelaskan oleh faktor lainnya yang tidak termasuk ke dalam penelitian. Angka koefisien determinasi yang didapat dalam persamaan kedua negara indonesia adalah sebesar 0,874, artinya variabel FDI inflows diterangkan oleh human development index, country risk, gross capital formation, dan index doing business sebesar $87,4 \%$ dan sisanya sebesar $12.6 \%$ dijelaskan oleh faktor lainnya yang tidak termasuk ke dalam penelitian. 


\section{PEMBAHASAN}

Hasil pengujian pada model pertama negara India menunjukkan koefisien FDI signifikan pada $\alpha=1 \%$ dan FDI memiliki nilai koefisien 0,0208. Berdasarkan hasil regresi tersebut dapat dikatakan bahwa jika arus masuk FDI ke India meningkat sebesar 1 miliar (\$), maka akan meningkatkan HDI sebesar 0,0208. Hubungan positif ini dapat diartikan bahwa semakin besar jumlah FDI masuk ke negara India maka akan dapat meningkatkan kualitas human capital yang ada di India. Dari hasil regresi tersebut dapat dikatakan bahwa masuknya investasi asing langsung akan meningkatkan human capital di India melalui transfer teknologi, spillover effect dan pembayaran pajak sehingga memberikan anggaran lebih untuk pemerintah menginvestasikannya di bidang human capital. Hal tersebut sejalan dengan penelitian Cheung dan Ping (2004) yang menyatakan investasi asing langsung (FDI) dapat memberikan keuntungan bagi negara tuan rumah melalui saluran spillover seperti reverse engineering, turnovers tenaga kerja terampil, demonstration effect, dan hubungan antara pemasok dengan pelanggan. Selain itu, Soltanpanah dan Karimi (2013) juga menunjukkan bahwa FDI yang masuk pada sebuah negara secara kolektif berkontribusi kepada lingkungan makro negara tersebut (kebjakan fiskal) lewat pajak. Pajak merupakan pendapatan negara yang selanjutnya digunakan untuk pembelanjaan negara. Maka hasil dari pajak dapat berupa infrastruktur untuk menunjang kegiatan ekonomi perusahaan atau juga dapat beupa infrastruktur yang menunjang peningkatan dari human capital seperti, infrastruktur untuk pendidikan dan kesehatan. Dalam penelitian tersebut Soltanpanah dan Karimi (2013) juga menambahkan bahwa memang hasil pajak tersebut belum tentu digunakan untuk investasi modal mausia, tetapi setidaknya membebaskan keterbatasan anggaran dan akan memungkinkan investasi pemerintah dengan anggaran yang lebih besar.

Koefisien variabel perubahan expenditure on education signifikan pada $\alpha=5 \%$ dengan nilai koefisien regresi sebesar 0,00524. Angka sebesar 0,00524 menjelaskan bahwa perubahan peningkatan pengeluaran pemerintah di sektor pendidikan sebesar 1\% akan meningkatkan HDI sebesar 0,00524 . Selain itu, koefisien variabel perubahan expenditure on health juga signifikan pada $\alpha=5 \%$ dengan nilai koefisien regresi sebesar 0,0354. Angka sebesar 0,0354 menjelaskan bahwa perubahan peningkatan pengeluaran pemerintah di sektor kesehatan sebesar $1 \%$ akan meningkatkan HDI sebesar 0,0354. Hubungan positif dari kedua variabel tersebut dapat diartikan semakin tinggi anggaran pemerintah India untuk sektor pendidikan dan kesehatan, maka akan meningkatkan kualitas human capital. Pembangunan infrastruktur, perbaikan sistem pelayanan dan penunjang dari kesehatan dan pendidikan akan membentuk sumberdaya manusia yang berkualitas baik. Selain itu alokasi dana lebih untuk sektor kesehatan dan pendidikan sangat berpengaruh bagi pembangunan ekonomi di negara berkembang seperti India. Hal tersebut diperkuat oleh penelitian dari Todaro (1993) yang menyatakan bahwa dampak investasi dalam modal manusia di negara-negara berkembang sangat besar. Investasi pada modal manusia dapat meningkatkan kualitas sumber daya manusia serta memiliki pengaruh yang besar terhadap kegiatan produksi dan pendapatan. Hasil regresi dari data negara India sejalan dengan apa yang sedang dilakukan oleh pemerintah yang sangat memerhatikan investasi modal manusia beberapa tahun terakhir dengan semakin meningkatnya persentase anggaran pemerintah untuk sektor pendidikan dan sektor kesehatan.

Koefisien variabel IDB signifikan pada $\alpha=1 \%$ dengan nilai koefisien sebesar $-0,33084$. Angka sebesar -0,33083 menjelaskan bahwa peningkatan angka IDB sebesar satu satuan akan menurunkan arus masuk FDI sebesar 330 juta (\$). Hal tersebut terjadi sesuai hipotesis awal karena memang semakin tinggi angka IDB berarti semakin sulit untuk melakukan bisnis (pajak tinggi, perizinan sulit dan pelanggaran kontrak sering terjadi). Hasil tersebut menunjukkan 
bahwa kebijakan mempermudah administrasi dalam berbisnis merupakan salah satu motif masuknya FDI ke India. Hasil regresi variabel IDB sejalan dengan apa yang di laporkan oleh World Investment Report (WIR). Dalam laporannya, kebijakan terkait investasi merupakan salah satu faktor kunci untuk FDI menanamkan modalnya di sebuah negara (WIR, 2010). Jika aturan dalam berbisnis di India semakin mudah, maka hal tersebut akan menjadi salah satu motif FDI masuk ke India. Hasil pengujian pada persamaan kedua di negara India menunjukkan koefisien dari HDI yang tidak signifikan, artinya nilai HDI tidak terlalu berpengaruh terhadap arus masuk FDI di India. Selain itu, koefisien variabel country risk, perubahan GCF, dan gross domestic bruto growth (GDP growth) tidak signifikan, artinya variabel-variabel tersebut tidak secara signifikan memengaruhi arus masuk FDI ke India.

Hasil pengujian pada persamaan pertama negara Indonesia menunjukkan koefisien FDI signifikan pada $\alpha=1 \%$ dan FDI memiliki nilai koefisien 0,001686 . Berdasarkan hasil regresi tersebut dapat dikatakan bahwa jika arus masuk FDI ke Indonesia meningkat sebesar 1 miliar (\$), maka akan meningkatkan nilai HDI sebesar 0,0016. Hubungan positif yang terjadi menggambarkan bahwa human capital Indonesia mendapat keuntungan dari masuknya FDI. Hasil tersebut sejalan dengan penelitian yang dilakukan oleh Soltanpanah dan Karimi (2013) yang menunjukkan bahwa bagi negara berkembang seperti Indonesia FDI akan memberikan pengaruh positif salah satunya terhadap akumulasi human capital. Negara berkembang akan mendapatkan teknologi dan pembelajaran baru dari perusahaan asing sementara perusahaan asing akan mendapatkan efisiensi di negara berkembang. Selain itu Blomstorm dan Kokko (seperti dikutip oleh Afin et al., 2008) juga mengatakan hal yang sejalan bahwa perusahaan multinasional karena adanya perdagangan internasional dan investasi asing seringkali dianggap sebagai sumber utama difusi teknologi dan pertumbuhan ekonomi negara tuan rumah. Dengan kata lain, perdagangan internasional dan investasi asing dianggap sebagai sumber transfer pengetahuan, kinerja dan teknologi, terutama dari negara maju ke negara sedang berkembang. Hal tersebut merupakan eksternalitas positif dari perdagangan internasional dan investasi asing. Dengan kata lain transfer teknologi memang terjadi ketika FDI masuk ke sebuah negara.

Koefisien variabel expenditure on education signifikan pada $\alpha=10 \%$ dengan nilai koefisien regresi sebesar 0,00242. Angka sebesar 0,00242 menjelaskan bahwa peningkatan pengeluaran pemerintah di sektor pendidikan sebesar $1 \%$ akan meningkatkan nilai HDI sebesar 0,00242. Namun koefisien variabel expenditure on health tidak signifikan bahkan pada $\alpha=10 \%$. Hubungan positif dari hasil regresi tersebut menggambarkan peran pemerintah dalam memberikan anggaran memengaruhi perubahan kualitas human capital yang ditunjukkan oleh nilai HDI. Hasil tersebut juga sejalan dengan Todaro (1993) yang menyatakan bahwa dampak investasi dalam modal manusia di negara-negara berkembang dapat meningkatkan kualitas sumber daya manusia serta memiliki pengaruh yang besar terhadap kegiatan produksi dan pendapatan.

Hasil pengujian pada persamaan kedua negara Indonesia menunjukkan koefisien dari HDI yang signifikan pada $\alpha=5 \%$ dengan nilai koefisien regresi sebesar 51,794. Angka sebesar 51,794 menjelaskan bahwa nilai HDI sebersar satu satuan akan meningkatkan arus masuk FDI sebesar 51,79 miliar \$. Hubungan positif tersebut menggambarkan kualitas human capital yang dicerminkan melalui HDI menjadi salah satu daya tarik FDI ke Indonesia. Dalam Dunning (1993) dikatakan salah satu orientasi dari FDI untuk masuk ke sebuah negara adalah tingkat keterampilan atau skill tenaga kerja. Maka semakin tinggi tingkat human capital di Indonesia akan meningkatkan arus masuk FDI karena perusahaan asing akan lebih efisien dalam melakukan kegiatan produksi dengan tenaga kerja yang produktif. 


\section{8 | Bina Ekonomi}

Koefisien variabel country risk signifikan pada $\alpha=5 \%$ dengan nilai koefisien regresi sebesar -70,66. Angka sebesar -70,66 menjelaskan bahwa penurunan angka country risk index (peningkatan risiko negara) sebesar satu satuan akan tetap meningkatkan arus masuk FDI sebesar 70,66 miliar \$. Hasil regresi menunjukkan penurunan CR akan tetap meningkatkan arus masuk FDI disebabkan nilai indeks country risk Indonesia sering berfluktuasi dan cenderung rendah. Jika berkaca pada hasil dari variabel CR di negara India, maka hasil dari variabel CR di Indonesia menunjukkan bahwa FDI yang masuk ke Indonesia lebih berani mengambil dari risiko karena sekalipun risiko negara Indonesia sedang meningkat (penurunan nilai country risk index) arus masuk FDI tetap meningkat.

Koefisen variabel pertumbuhan Gross Domestic Product (GDP growth) signifikan pada $\alpha=5 \%$ dengan nilai koefisien sebesar 5,448. Angka sebesar 5,448 menjelaskan bahwa peningkatan angka GDP growth sebesar 1\% akan meningkatkan arus masuk FDI sebesar 5,44 miliar (\$). GDP growth menggambarkan peningkatan ukuran pasar sehingga negara yang mengalami pertumbuhan GDP dapat menjadi basis wilayah dalam melakukan penjualan. GDP yang terus tumbuh dari tahun ke tahun menggambarkan daya beli masyarakat yang semakin meningkat. Hal tersebut juga dijelaskan oleh Dunning (1993) Bagi market-seeker investors, luas pasar dan pertumbuhan pasar suatu negara merupakan alasan penting dalam memilih lokasi FDI. Maka dari itu, Hubungan positif hasil regresi tersebut menujukkan bahwa FDI yang masuk ke Indonesia berorientasi pada pasar.

Koefisien variabel IDB signifikan pada $\alpha=1 \%$ dengan nilai koefisien sebesar $-0,153$. Angka $-0,153$ menjelaskan peningkatan angka IDB sebesar satu satuan akan menurunkan arus masuk FDI sebesar 153 juta (\$). Sesuai dengan hipotesis awal karena memang semakin tinggi angka IDB berarti semakin sulit untuk melakukan bisnis (pajak tinggi, perizinan sulit dan pelanggaran kontrak sering terjadi). Hasil tersebut menunjukkan bahwa kebijakan mempermudah administrasi dalam berbisnis merupakan salah satu motif masuknya FDI ke Indonesia. Hasil regresi variabel IDB sejalan dengan apa yang di laporkan oleh World Investment Report (WIR). Dalam laporannya WIR (2010), mengatakan kebijakan terkait investasi merupakan salah satu faktor kunci untuk FDI menanamkan modalnya di sebuah negara. Jika aturan dalam berbisnis di Indonesia semakin mudah maka hal tersebut akan menjadi salah satu motif FDI masuk ke Indonesia. Hasil pengujian pada persamaan kedua di negara Indonesia menunjukkan hanya koefisien dari perubahan GCF yang tidak signifikan, artinya nilai GCF tidak terlalu berpengaruh terhadap arus masuk FDI di Indonesia.

\section{SIMPULAN DAN SARAN}

Penelitian ini bertujuan untuk menguji adanya hubungan kausal antara kualitas human capital dan arus masuk FDI serta orientasi FDI seperti apa yang masuk ke Indonesia dan India. Hasil dari penelitian ini menunjukkan bahwa terdapat hubungan timbal balik antara kualitas human capital dan arus masuk FDI di Indonesia. Sedangkan antara kualitas human capital dan arus masuk FDI di India tidak terjadi hubungan timbal balik, di mana arus masuk FDI memengaruhi kualitas human capital namun kualitas human capital tidak memengaruhi arus masuk FDI.

Di India, arus masuk FDI berpengaruh positif terhadap kualitas human capital. Di mana peningkatan arus masuk FDI dapat meningkatkan kualitas human capital. FDI berpengaruh positif terhadap kualitas human capital melalui transfer teknologi, spillover effect dan pembayaran pajak 
sehingga memberikan tambahan anggaran pemerintah untuk dialokasikan pada bidang modal manusia. Perubahan pengeluaran pemerintah di sektor pendidikan dan kesehatan juga berpengaruh positif terhadap kualitas human capital. Hal tersebut menggambarkan betapa pentingnya peran pemerintah untuk sektor pendidikan dan kesehatan terutama melalui penetapan anggaran belanja negara di sektor tersebut.

Index Doing Business berpengaruh negatif terhadap arus masuk FDI di India. Semakin tinggi angka IDB berarti semakin sulit untuk melakukan bisnis (pajak tinggi, perizinan sulit dan pelanggaran kontrak sering terjadi), artinya semakin mudah administrasi dalam berbisnis akan semakin meningkatkan arus masuk FDI. Hasil tersebut menunjukkan bahwa kebijakan mempermudah administrasi dalam berbisnis merupakan salah satu daya tarik bagi masuknya FDI ke India. Variabel yang tidak signifikan berpengaruh terhadap arus masuk FDI di India yaitu kualitas human capital, risiko negara India, perubahan nilai infrastruktur dan pertumbuhan GDP.

Di Indonesia, arus masuk FDI berpengaruh positif terhadap kualitas human capital. Negara berkembang seperti Indonesia akan mendapatkan teknologi dan pembelajaran baru dari perusahaan asing. Perubahan pengeluaran pemerintah di sektor pendidikan dan kesehatan juga berpengaruh positif terhadap kualitas human capital. Pengaruh investasi dalam modal manusia di negara-negara berkembang sangat besar. Investasi pada modal manusia dapat meningkatkan kualitas sumber daya manusia serta memiliki pengaruh yang besar terhadap kegiatan produksi dan pendapatan. Hal tersebut menggambarkan betapa pentingnya peran pemerintah untuk sektor pendidikan dan kesehatan terutama melalui penetapan anggaran belanja negara agar dapat menunjang investasi modal manusia.

Tingkat human capital berpengaruh positif terhadap arus masuk FDI. Hal tersebut disebabkan salah satu orientasi dari FDI untuk masuk ke sebuah negara adalah tingkat keterampilan atau skill tenaga kerja. Maka semakin tinggi tingkat human capital di Indonesia akan semakin tinggi juga arus masuk FDI karena perusahaan asing akan lebih efisien dalam melakukan kegiatan produksi dengan tenaga kerja yang produktif.

Risiko negara Indonesia berpengaruh negatif terhadap arus masuk FDI. Di mana peningkatan risiko yang disebabkan tidak kondusifnya sebuah negara akan tetap meningkatkan arus masuk FDI ke Indonesia. Hal tersebut terjadi karena orientasi FDI masuk ke Indonesia mencari pasar, sehingga kondisi stabilitas negara yang dapat memengaruhi kegiatan produksi dan nilai tukar (untuk ekspor) tidak menjadi halangan bagi investor asing.

Pertumbuhan GDP berpengaruh positif terhadap arus masuk FDI ke Indonesia. Di mana peningkatan pertumbuhan GDP akan dapat meningkatkan arus masuk FDI. Hal tersebut menggambarkan bahwa FDI yang masuk ke Indonesia mencari pasar. GDP growth menggambarkan peningkatan ukuran pasar sehingga negara yang mengalami peningkatan pertumbuhan GDP dapat menjadi basis wilayah dalam melakukan penjualan. GDP yang terus tumbuh dari tahun ke tahun menggambarkan daya beli masyarakat yang semakin meningkat.

Index Doing Business berpengaruh negatif terhadap arus masuk FDI di Indonesia. Semakin tinggi angka IDB berarti semakin sulit untuk melakukan bisnis (pajak tinggi, perizinan sulit dan pelanggaran kontrak sering terjadi), dengan kata lain semakin mudah administrasi dalam berbisnis akan semakin meningkatkan arus masuk FDI. Jika aturan dalam berbisnis di Indonesia semakin mudah maka hal tersebut akan menjadi daya tarik bagi FDI masuk ke Indonesia. Variabel yang tidak signifikan berpengaruh terhadap arus masuk FDI di Indonesia yaitu perubahan nilai 


\section{0 | Bina Ekonomi}

infrastruktur.

Dari hasil tersebut dapat disimpulkan FDI yang masuk ke India berorientasi pada ekspor atau pasar mancanegara. Sementara FDI yang masuk ke Indonesia hanya berorientasi pada pasar domestik. Maka dari itu, arus masuk FDI yang masuk ke India lebih bernilai besar dibandingkan arus masuk FDI ke Indonesia karena target pasar produk perusahaan asing yang masuk ke India lebih luas dibandingkan perusahaan asing yang masuk ke Indonesia.

Sebagai implikasi dari penelitian ini, sebaiknya pemerintah Indonesia dapat membuat anggaran yang tepat bagi sektor-sektor yang dapat meningkatkan kualitas human capital. Selain itu perlu dibuat lebih banyak kebijakan yang output-nya menghasilkan sumber daya manusia dengan kualitas baik. Salah satu kebijakan yang dapat meningkatkan kualitas human capital adalah mempermudah aturan terkait investasi asing (pajak, perizinan, dan aturan kontrak). Hal tersebut perlu dilakukan karena jika mengacu apa yang terjadi di India, motif FDI masuk adalah kualitas sumber daya manusianya. Dengan begitu, investasi asing yang nantinya akan memiliki multiplier effect terhadap kualitas sumber daya manusia negara itu sendiri dan akan terus menjadi siklus yang baik karena kualitas sumber daya manusia juga memiliki pengaruh baik terhadap arus masuk FDI (virtuous circle).

Penelitian berikutnya dapat menambah periode waktu dan menggunakan GDP growth sebagai variabel dependen. Hal tersebut dilakukan agar penelitian berikutnya dapat melihat pengaruh dan keterkaitannya terhadap pertumbuhan ekonomi. Dengan demikian, saran-saran tersebut diharapkan dapat menjadi bahan untuk memperkaya penelitian serupa selanjutnya.

\section{DAFTAR PUSTAKA}

Afin, R., Yulistiono, H., \& Oktarani, N. A. (2008). Perdagangan internasional, investasi asing, dan efisiensi perekonomian negara-negara ASEAN. Buletin Ekonomi Moneter dan Perbankan, 10(3), 261-296.

Arifin, M. Y., Suswandi, P. E., \& Adenan, M. (2015). Pengaruh pengeluaran pemerintah sektor kesehatan, pengeluaran pemerintah sektor pendidikan, dan pertumbuhan ekonomi terhadap indeks pembangunan manusia Jawa Timur 2006-2013. Jurnal Universitas Jember.

Blomstorm, M., \& Kokko, A. (2002). FDI and human capital: a research agenda. OECD Development Centre.

Brata, A. G. (2004). Analisis hubungan timbal balik antara pembangunan manusia dan kinerja ekonomi Daerah Tingkat II di Indonesia. Lembaga Penelitian-Universitas Atma Jaya.

Cheung, K. Y., \& Ping, L. (2004). Spillover effect of FDI on innovation in China: evidence from the provincial data. China Economic Review, 15(1), 25-44. doi:10.1016/S1043951X(03)00027-0

Dikit, S. V., \& Shringarpure, A. A. (2013). Exchange rate - a key determinant of FDI in India. Advances in Management, 6(9), 55-57.

Dorozynska, A., \& Dorozynski, T. (2015). Human capital and FDI in central and eastern europe. Managing Global Transitions, 13(2), 151-170. 
Dua, P., \& Garg, R. (2015). Macroeconomics determinants of foreign direct investment: evidence from India. The Journal of Developing Areas, 49(1).

Dunning, J. H. (1993). Multinasional enterprises and the global economy. Wokingham, England: Addison-Wesley Publishing Company.

Kar, S. (2013). Exploring the causal link between FDI and human capital development in India. India Institute of Management Calcutta, 40(1-2), 3-13.

Kementerian Keuangan Republik Indonesia. (2014). Data pokok APBN 2010-2014. Jakarta: Kementerian Keuangan Republik Indonesia.

Kurniati, Y., Prasmuko, A., \& Yanfitri. (2007). Determinan FDI (faktor-faktor yang menentukan investasi asing langsung). Working Paper.

McConnell, C. R., Brue, S. L., \& Macpherson, D. A. (2010). Contemporary labor economics (9th ed.). New York: The McGraw-Hill Companies.

Mello, L., \& Fukusaku, K. (2000). Trade and foreign direct investment in Latin America and Southeast Asia: temporal causality analysis. Journal of International Development, 12 (7), 903-924. doi:10.1002/1099-1328(200010)12:7<903::AID-JID695>3.0.CO;2-8

Nafukho, F. M., Hairston, N. R., \& Brooks, K. (2004). Human capital theory: implication for human resource development. Human Resource Development International, 7(4), 545-551. doi: $10.1080 / 1367886042000299843$

Razin, A., \& Sadka, E. (2000). Unskilled migration: a burden or a boon for the welfare state? The Scandinavian Journal of Economics, 102(3), 463-479. doi:10.1111/1467-9442.00210

Salvatore, D. (2013). International economics (11th ed.). New York: Wiley.

Sarwedi, S. (2004). Investasi asing langsung di Indonesia dan faktor yang memengaruhinya. Jurnal Akutansi dan Keuangan, 4(1), 17-35. doi: 10.9744/jak.4.1.pp.\%2017-35

Soltanpanah, H., \& Karimi, M. S. (2013). Accumulation of human capital and foreign direct investment (FDI) inflows in ASEAN-3 countries (Malaysia, Thailand, Indonesia). African Journal of Business Management, 17(7), 1599-1605. doi:10.5897/AJBM11.1681

Tjiptoherijanto, P., Yasin, M., Hasan, B., \& Hadisumarto, D. (1982). Sumber daya manusia, kesempatan kerja dan pembangunan ekonomi. Jakarta: Lembaga Penerbit Fakultas Ekonomi Universitas Indonesia.

Todaro, M. P. (1993). Pembangunan ekonomi di dunia ketiga (3rd ed.). (B. Abdullah, Trans.) Jakarta: Gelora Aksara Pratama.

Todaro, M. P., \& Smith, S. C. (2006). Economics development (9th ed.). London: Pearson Education.

World Bank Group. (2014). Doing Business 2015 Going Beyond Efficiency. Washington DC: International Bank for Reconstruction and Development / The World Bank . doi:10.1596/978-1-4648-0351-2

World Bank Group. (2016). World development indicators 2016. World Bank Publications. 
82 | Bina Ekonomi

World Investment Report. (2010). The global competitiveness report 2010. Geneva: World Economic Forum. 
LAMPIRAN 1. Data yang Digunakan dalam Penelitian

\begin{tabular}{|c|c|c|c|c|c|c|c|c|c|c|c|c|c|c|c|c|}
\hline \multirow[b]{2}{*}{ Tahun } & \multicolumn{8}{|c|}{ Indonesia } & \multicolumn{8}{|c|}{ India } \\
\hline & HDI & $\begin{array}{l}\text { Peng } \\
\text { Pend } \\
(\%)\end{array}$ & $\begin{array}{l}\text { Peng } \\
\text { Kes } \\
(\%)\end{array}$ & $\begin{array}{l}\text { FDI } \\
(\mathrm{Mil} \$)\end{array}$ & $\begin{array}{l}\text { Indeks } \\
\text { Risiko } \\
\text { Negara }\end{array}$ & $\begin{array}{l}\text { Gross } \\
\text { Cap. } \\
\text { For. } \\
\text { (Mil \$) }\end{array}$ & $\begin{array}{l}\text { Pert } \\
\text { PDB } \\
(\%)\end{array}$ & $\begin{array}{l}\text { Indeks } \\
\text { Kemud. } \\
\text { Bisnis }\end{array}$ & HDI & $\begin{array}{l}\text { Peng. } \\
\text { Pend. } \\
(\%)\end{array}$ & $\begin{array}{l}\text { Peng. } \\
\text { Kes. } \\
(\%)\end{array}$ & $\begin{array}{l}\text { FDI } \\
(\mathrm{Mil} \$)\end{array}$ & $\begin{array}{l}\text { Indeks } \\
\text { Risiko } \\
\text { Negara }\end{array}$ & $\begin{array}{l}\text { Gross } \\
\text { Cap. } \\
\text { For. } \\
\text { (Mil \$) }\end{array}$ & $\begin{array}{l}\text { Pert } \\
\text { PDB } \\
(\%)\end{array}$ & $\begin{array}{l}\text { Indeks } \\
\text { Kemud. } \\
\text { Bisnis }\end{array}$ \\
\hline 2000 & 0,61 & 8,82 & 4,05 & $-4,550$ & 0,49 & 36,710 & 4,92 & 204,45 & 0,49 & 17,5 & 14,39 & 3,584 & 0,59 & 114,933 & 3,84 & 165,05 \\
\hline 2001 & 0,61 & 11,6 & 4,34 & $-2,977$ & 0,57 & 36,163 & 3,64 & 173,57 & 0,5 & 15,9 & 4,25 & 5,128 & 0,6 & 126,318 & 4,82 & 149,56 \\
\hline 2002 & 0,62 & 14,37 & 4,8 & 0,145 & 0,64 & 41,879 & 4,5 & 168,51 & 0,5 & 14,3 & 3,82 & 5,209 & 0,62 & 130,826 & 3,8 & 146,33 \\
\hline 2003 & 0,62 & 16,28 & 4,34 & $-0,597$ & 0,63 & 60,098 & 4,78 & 167,88 & 0,51 & 12,9 & 3,6 & 3,682 & 0,63 & 161,627 & 7,86 & 144,47 \\
\hline 2004 & 0,63 & 14,17 & 4,82 & 1,896 & 0,61 & 61,786 & 5,03 & 146,42 & 0,52 & 11,6 & 4,04 & 5,429 & 0,67 & 234,184 & 7,92 & 127,83 \\
\hline 2005 & 0,63 & 15,15 & 4,74 & 8,336 & 0,61 & 71,700 & 5,7 & 122,8 & 0,53 & 11,53 & 4,51 & 7,269 & 0,67 & 285,966 & 9,28 & 102,72 \\
\hline 2006 & 0,64 & 15,05 & 4,94 & 4,914 & 0,63 & 92,602 & 5,5 & 103,53 & 0,54 & 11,8 & 4,4 & 20,029 & 0,66 & 340,464 & 9,26 & 82,02 \\
\hline 2007 & 0,65 & 15 & 5,03 & 6,928 & 0,63 & 107,710 & 6,35 & 96,86 & 0,55 & 12 & 4,43 & 25,228 & 0,65 & 510,004 & 8,61 & 56,37 \\
\hline 2008 & 0,65 & 13,67 & 5,14 & 9,318 & 0,62 & 141,926 & 6,01 & 72,71 & 0,56 & 11,43 & 4,34 & 43,406 & 0,65 & 453,625 & 3,89 & 52,89 \\
\hline 2009 & 0,66 & 19,31 & 5,58 & 4,877 & 0,64 & 167,190 & 4,63 & 46,87 & 0,58 & 10,82 & 4,37 & 35,581 & 0,66 & 538,067 & 8,48 & 47,87 \\
\hline 2010 & 0,67 & 16,65 & 6,12 & 15,292 & 0,62 & 248,276 & 6,22 & 39,88 & 0,59 & 11,74 & 4,3 & 27,397 & 0,65 & 673,695 & 10,26 & 45,55 \\
\hline 2011 & 0,67 & 18,1 & 5,83 & 20,565 & 0,61 & 294,540 & 6,17 & 37,42 & 0,6 & 13,7 & 4,42 & 36,499 & 0,63 & 721,494 & 6,64 & 43,15 \\
\hline 2012 & 0,68 & 18,1 & 6,1 & 21,201 & 0,55 & 321,912 & 6,03 & 37,42 & 0,6 & 14,1 & 4,49 & 23,996 & 0,63 & 699,800 & 5,62 & 42,17 \\
\hline 2013 & 0,68 & 17,6 & 6,03 & 23,282 & 0,57 & 308,720 & 5,56 & 36,38 & 0,6 & 14,45 & 4,66 & 28,153 & 0,63 & 645,810 & 6,64 & 43,11 \\
\hline 2014 & 0,68 & 17,51 & 6,73 & 26,277 & 0,59 & 307,827 & 5,02 & 40,02 & 0,61 & 14,84 & 5,05 & 33,871 & 0,64 & 696,325 & 7,24 & 43,45 \\
\hline 2015 & 0,69 & 17,42 & 7,43 & 15,508 & 0,56 & 297,902 & 4,8 & 31,65 & 0,61 & 15,22 & 5,44 & 44,208 & 0,67 & 678,238 & 7,57 & 38,83 \\
\hline
\end{tabular}


84| Bina Ekonomi

Halaman ini sengaja dikosongkan 